THE WHITE UMBRLLA 
VASISHTHA INSTALLED RAMA UPON A GOLDEN

THRONE WROUGHT WITH JEWELS AND

SATRUGHNA PLACED A WHITE UMBRELLA OVER HIS HEAD

Rāmāyaṇa 


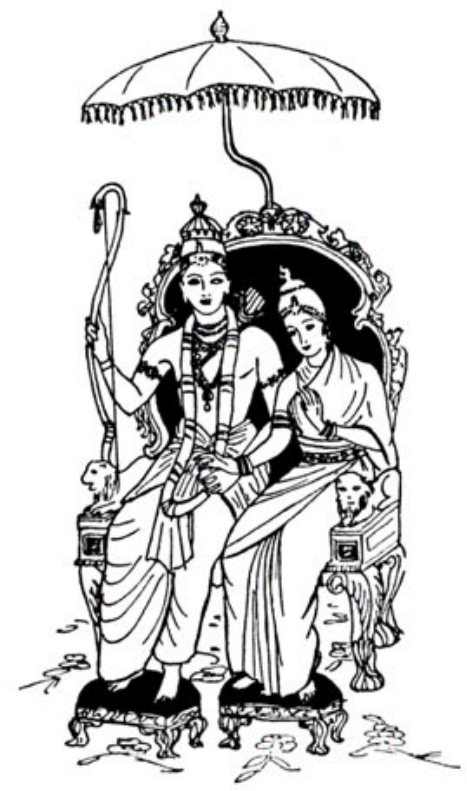

\section{The White Umbrella}

Indian Political Thought from Manu to Gandhi. By D. Mackenzie Brown

UNIVERSITY OF CALIFORNIA PRESS BERKELEYANDLOSANGELES 
TO DEB AND KEN

University of California Press - Berkeley and Los Angeles Cambridge University Press • London, England Copyright 1953 by The Regents of the University of California Fourth Printing, 1964 (First Paper-bound edition, Third Printing) Printed in the United States of America 